\title{
Influence of grain processing in regard to serum metabolites and enzymes for finishing bull calves*
}

\author{
C. Castillo ${ }^{1,5}$, J.L. Benedito ${ }^{1}$, V. Pereira ${ }^{1}$, J. Sotillo ${ }^{2}$, A. Suárez ${ }^{1}$, \\ J. Méndez ${ }^{3}$, P. Vázquez ${ }^{4}$ and J. Hernández ${ }^{1}$
}

\author{
${ }^{1}$ University of Santiago de Compostela, Department of Animal Pathology, \\ Veterinary Faculty \\ Campus Universitario s/n, 27002, Lugo, Spain \\ ${ }^{2}$ University of Murcia, Department of Animal Medicine and Surgery, Veterinary Faculty \\ Campus de Espinardo, 30100 Murcia, Spain \\ ${ }^{3}$ Technical Department of COREN \\ SCL 32003 Ourense, Spain \\ ${ }^{4}$ IMASDE Agroalimentaria \\ 28224 Madrid, Spain
}

(Received 2 March 2011; revised version 12 August 2011; accepted 6 December 2011)

\begin{abstract}
This study compared two grain processing methods that are widely used for beef cattle, grinding and steam pelleting, with respect to serum metabolic parameters: glucose, non-esterified fatty acids (NEFA), serum urea nitrogen (SUN), total serum protein (TSP), albumin, L-lactate, aspartate aminotransferase (AST), $\gamma$-glutamyltransferase (GGT) and amylase. Ten Belgian Blue bull calves were allotted randomly to each of two experimental groups: PF, fed pelleted concentrate, and GF, fed ground concentrate. During the 77-day study most parameters underwent significant variation in time, increasing only numerically serum values of total protein, albumin, AST and amylase, while serum glucose, NEFA and GGT decreased numerically. Statistically significant differences were found only between groups PF and GF for creatinine (higher in group PF, in relation with its greater average body weight) and urea nitrogen, which for unknown causes fluctuated in opposite directions in the two groups throughout most of the study and attributable to changes in ruminal protein digestion. Neither serum glucose nor L-lactate were affected by treatment of grains.
\end{abstract}

KEY WORDS: ground grain, pelleted grain, blood parameters, feedlot, bull calves

\footnotetext{
${ }^{*}$ Supported by the Xunta de Galicia (Spain), Grant XUGA 2002/CG320

${ }^{5}$ Corresponding author: e-mail: cristina.castillo@usc.es
} 


\section{INTRODUCTION}

For high-output production, feedlot calves require a high-energy diet component such as starch, which is readily supplied in the form of cereal grains, of which it is a major component. However, whole, unprocessed grains can be relatively indigestible. It is well-known that starch availability increases with processing grains, although considerable differences have been detected between grain processing facilities (Brown et al., 2000). The grain processing methods predominantly used in the production of Spanish cattle feeds are grinding and steam pelleting. Grinding destroys mechanical structure, exposing more starch to microbial digestion, but does not alter chemical structure. By contrast, steam pelleting not only increases moisture content, but also disrupts the starch-protein matrix, which facilitates microbial and enzymatic access to starch granules (Dehghan-Banadaky et al., 2007).

Research on the effects of grain processing in recent years has mainly examined production parameters such as dry matter intake, average daily gain (ADG) and feed efficiency (Owens et al., 1997). However, it has been reported that increasing the proportion of starch digested in rumen results in greater absorption and different partitioning of nutrients by gut and liver tissues, with consequences for animal metabolism and health. Controlled studies have considered the measurement of ruminal $\mathrm{pH}$; however, sampling ruminal contents for $\mathrm{pH}$ measurement is not practical in a commercial feedlot situation. Then, the clinical chemistry profile is a valuable diagnostic tool that can be used to evaluate the internal balance. When used in conjunction with the physical examination the chemistry panel is useful for establishing initial baseline parameters, formulating a problem or rule out list, planning nutritional options and monitoring the response to it (Castillo et al., 2011).

In line with this idea, we continued our previous researches (Castillo et al., 2006) regarding the effects of grain processing on acid-base balance. In that study, we found that although animals fed a pelleted ration had better productive results, their lower base excess and $\mathrm{HCO}_{3}^{-}$values reflected a greater risk of acid overload, more evident in the finishing period. In the current report, we focus on this stage, when it is possible to observe the carryover effect of diet, reflected in animal performance and/or metabolic status.

In the belief that it is also of interest to investigate these issues under the conditions of commercial operations, in the study described here we compare serum metabolic parameters of bull calves fed diets based on ground or pelleted grain throughout the 77-day finishing period implemented on a commercial feedlot in Galicia (NW Spain). 


\section{MATERIAL AND METHODS}

\section{Animals, feed management and experimental design}

Twenty double-muscled Belgian Blue bull calves were purchased and transported to the commercial study farm (Coren SCL, Ourense, NW Spain) at age of 3-5 weeks. Upon arrival, animals were under sanitary protocols and animal welfare conditions as was described in previous reports (Castillo et al., 2011) and according to Spanish regulations.

Adaptation to the high-grain diet was carried out until age 14 weeks with a combination of milk replacer [1 1 per $20 \mathrm{~kg}$ of body weight (BW)] and a farmformulated mixture of maize, wheat, barley, soyabean meal and vitamin-mineral premix (Table 1), with water and straw ad libitum. Before the first intake of growing concentrate, calves were allotted randomly to one of two 10-calf groups housed in individual pens: $\mathrm{PF}$, fed pelleted concentrate obtained by grinding grains to 3 $\mathrm{mm}$, mixing in the other components and converting the mixture to $4 \mathrm{~mm}$ pellets at $70^{\circ} \mathrm{C}$; and $\mathrm{GF}$, fed concentrate with grains ground to $5 \mathrm{~mm}$. All the grain used in the trial came from the same lot, and all processed grain was obtained during a single processing run.

Table 1. Ingredients of mixture and chemical composition of the finishing concentrate, $\mathrm{g} / \mathrm{kg}$

\begin{tabular}{|c|c|}
\hline Item & \\
\hline Ingredient, $\mathrm{g} / \mathrm{kg} D M$ & \\
\hline barley & 329 \\
\hline maize & 275 \\
\hline molasses & 33 \\
\hline palm kernel oil & 40 \\
\hline palm oil ( $98 \%$ bypass) & 16 \\
\hline soyabean meal $(44 \% \mathrm{CP})$ & 129 \\
\hline maize gluten & 140 \\
\hline soyabean hulls & 16 \\
\hline vitamin/mineral premix ${ }^{1}$ & 22 \\
\hline $\begin{array}{l}\text { Chemical composition, } \mathrm{g} / \mathrm{kg} \\
\text { crude protein }\end{array}$ & \\
\hline crude fibre & 50 \\
\hline NDF & 193 \\
\hline $\mathrm{ADF}$ & 68 \\
\hline ether extract ${ }^{2}$ & 41 \\
\hline $\mathrm{N}$-free extractives ${ }^{2}$ & 566 \\
\hline ash & 50 \\
\hline
\end{tabular}


Then, between ages 14 and 23 weeks (the growing period in the Spanish feedlot system), the animals were fed growing concentrate with the following composition, g/kg dry matter (DM): grains (barley, 270; wheat, 60 and maize, 250); molasses, 33; palm oil (98\% bypass), 19; soyabean meal, 165; maize gluten feed, 140; barley sprouts, 20; soyabean hulls, 15; vitamin/mineral supplement, 28. The chemical composition of the growing diet, $\mathrm{g} / \mathrm{kg} \mathrm{DM}$, was: crude protein (CP) 165, neutral detergent fibre (NDF) 175, acid detergent fibre (ADF) 60, ether extract (EE) 40 and non-fibre carbohydrates (NFC) 563. Differences between groups were only in the grain processing method employed.

The main study period began when at age 23 weeks the calves were put on a finishing concentrate (Table 1), and continued for 77 days until age 34 weeks, previous to slaughter. Additionally, production performance was evaluated in the slaughterhouse 45 days after the last sampling of data. During this interval animals maintained the same nutritional protocol.

Feed refusals were weighed daily at $07.30 \mathrm{~h}$ before feeding, and daily intake of concentrate and straw calculated. In our study, daily barley straw intake was 1.5 $\mathrm{kg} / \mathrm{head}$. Fresh feed was provided once a day at $08.00 \mathrm{~h}$. During both the growing and finishing periods, all calves had free access to concentrate, water and barley straw, which was chopped to a length of 7-8 $\mathrm{cm}$. Feed:gain ratio was calculated as follows: $\mathrm{kg}$ feed consumed $/ \mathrm{kg}$ weight gained. Individual steers were weighed at the beginning and the end of the experiment. All experimental procedures were approved by the Ethical Committee of the University of Santiago de Compostela and, more generally, the animals were cared for and managed throughout the study in accordance with official Spanish guidelines on animal care (Real Decreto 1201/2005).

\section{Measurements and analyses}

Samples of concentrate were analysed in the farm laboratory. European Union standard methods and European Directive were used for determination of starch (1999/79/EC, 1999), ether extract (1998/64/EC, 1988) and ash (1981/680/ EC, 1981). Neutral detergent fibre (NDF) and acid detergent fibre (ADF) were determined by the method of Van Soest et al. (1991) and nitrogen content using the method by combustion according to the Dumas principle (Norme Française NFV18-120, 1997) described in NFV18-120 by the French Association of Standardization (AFNOR, Paris)

On days 0 (the end of the growing period and the beginning of the fattening diet), 3, 7, 13, 51 and 77 of the study, between 09.00 and $11.00 \mathrm{~h}$ (always following feed delivery) blood samples were collected by jugular venous puncture into evacuated Vacutainer ${ }^{\circledR}$ tubes without EDTA. On each occasion, the calves were examined before blood sampling for clinical signs of metabolic disturbances, i.e. 
for changes in posture and/or behaviour, signs of dehydration or shock (anomalies in eyeball position or mouth or limb temperatures), diarrhoea, and altered palpebral reflex (Lorenz, 2004). The samples were allowed to clot at room temperature for $3 \mathrm{~h}$ before centrifugation at $2000 \mathrm{~g}$ for $20 \mathrm{~min}$, and the supernatant serum was frozen at $-20^{\circ} \mathrm{C}$ pending analysis.

The serum parameters studied were: glucose, non-esterified fatty acids (NEFA), urea nitrogen (SUN), creatinine, total protein concentration (TSP), albumin, L-lactate, aspartate aminotransferase (AST), gamma-glutamyl-transferase (GGT) and amylase. Glucose, SUN, creatinine, albumin, total protein and AST were assayed with kits from RAL Laboratories S.A. (Barcelona, Spain), NEFA with a kit from Randox Laboratories Ltd. (Crumlin, UK), and L-lactate, GGT and amylase with kits from Spinreact Laboratories S.A. (Girona, Spain). Within-run and within-day coefficients of variation established using appropriate controls were less than the limits of 5 and $10 \%$, respectively, that were recommended (Lumsden, 2000).

\section{Statistical analysis}

Non-normal distributions were tested for using the Wilk-Shapiro test. Analyses of variance (ANOVAs) were performed with group (G) as a fixed effect and time (T; days since the start of the finishing period) as a repeated measures effect, with the group $\times$ time interaction $(\mathrm{G} \times \mathrm{T})$ included in the model. All statistical analyses were performed using SPSS 12.1. The criterion for statistical significance was $\mathrm{P}<0.05$; $\mathrm{P}$ values between 0.05 and 0.1 were considered near-significant.

\section{RESULTS}

Mean values of non-enzymatic variables in each group on each sampling date are listed in Table 2. Groups PF and GF did not differ significantly in regard to either serum glucose or NEFA levels, but both of these variables varied significantly with time in the whole study ( $\mathrm{P}=0.05$ and $\mathrm{P}=0.01$, respectively). Serum L-lactate was not significantly influenced by either time or group, although the mean L-lactate level was always higher in group PF than in group GF. Albumin and total protein concentrations, particularly the latter, both tended to rise as time elapsed $(\mathrm{P}<0.001)$, with virtually no difference between groups at any time, especially in the case of albumin. SUN was not significantly influenced by either time or group, but was the only variable to show a significant $(\mathrm{G} \times \mathrm{T})$ interaction, the two groups generally showing opposite changes between successive samples. By contrast, the two groups always underwent parallel changes in serum creatinine levels, resulting in significant effects of both group and time $(\mathrm{P}<0.001)$, although the $\mathrm{G} \times \mathrm{T}$ interaction tended to be significant $(\mathrm{P}=0.06)$. 
Table 2. Mean values of serum glucose, NEFA, L-lactate, TSP, albumin, SUN and creatinine during the study. P values for the effects of time (T) and group (G), and the $\mathrm{G} \times \mathrm{T}$ interaction

\begin{tabular}{|c|c|c|c|c|c|c|c|c|c|c|c|}
\hline \multirow{2}{*}{ Variable } & \multicolumn{6}{|c|}{ Day } & \multicolumn{2}{|c|}{ Mean \pm} & \multicolumn{3}{|c|}{$\mathrm{P}$} \\
\hline & 0 & 3 & 7 & 13 & 51 & 77 & pooled & $\mathrm{SEM}^{3}$ & $\mathrm{~T}$ & $\mathrm{G}$ & $\mathrm{G} \times \mathrm{T}$ \\
\hline \multicolumn{12}{|c|}{ Glucose, $\mathrm{mg} / \mathrm{dl}$} \\
\hline $\mathrm{PF}^{1}$ & 101.4 & 100.0 & 106.4 & 99.0 & 95.6 & 93.2 & 99.3 & 1.4 & 0.05 & 0.90 & 0.3 \\
\hline $\mathrm{GF}^{2}$ & 96.6 & 101.4 & 101.6 & 97.8 & 103.5 & 93.2 & 99.2 & & & & \\
\hline \multicolumn{12}{|c|}{ NEFA, mmol/1 } \\
\hline PF & 0.53 & 0.46 & 0.43 & 0.43 & 0.49 & 0.46 & 0.46 & 0.11 & 0.01 & 0.42 & 0.65 \\
\hline GF & 0.56 & 0.41 & 0.42 & 0.43 & 0.48 & 0.41 & 0.45 & & & & \\
\hline \multicolumn{12}{|l|}{ L-lactate } \\
\hline PF & 0.97 & 0.50 & 0.84 & 0.46 & 0.68 & 0.60 & 0.68 & 0.06 & 0.42 & 0.13 & 0.31 \\
\hline GF & 0.65 & 0.42 & 0.56 & 0.39 & 0.60 & 0.46 & 0.53 & & & & \\
\hline \multicolumn{12}{|l|}{ TSP, g/dl } \\
\hline PF & 6.42 & 6.77 & 6.49 & 6.90 & 7.71 & 7.46 & 6.96 & 0.13 & 0.001 & 0.91 & 0.81 \\
\hline GF & 6.53 & 6.53 & 6.83 & 6.94 & 7.34 & 7.70 & 6.98 & & & & \\
\hline \multicolumn{12}{|c|}{ Albumin, g/dl } \\
\hline PF & 3.88 & 3.88 & 4.02 & 4.11 & 4.04 & 4.14 & 4.01 & 0.02 & $<0.001$ & 0.87 & 0.94 \\
\hline GF & 3.88 & 3.84 & 4.02 & 4.10 & 4.04 & 4.15 & 4.01 & & & & \\
\hline \multicolumn{12}{|c|}{$\mathrm{SUN}, \mathrm{mg} / \mathrm{dl}$} \\
\hline PF & 26.6 & 25.8 & 24.8 & 26.6 & 21.6 & 23.8 & 24.9 & 2.1 & 0.41 & 0.69 & 0.01 \\
\hline GF & 24.4 & 19.2 & 24.6 & 23.2 & 26.7 & 23.6 & 23.6 & & & & \\
\hline \multicolumn{12}{|c|}{ Creatinine, mg/dl } \\
\hline PF & 1.22 & 1.39 & 1.51 & 1.34 & 1.36 & 1.11 & 1.32 & 0.02 & $<0.001$ & 0.001 & 0.06 \\
\hline GF & 1.04 & 1.21 & 1.29 & 1.11 & 1.29 & 1.05 & 1.17 & & & & \\
\hline
\end{tabular}

${ }^{1} \mathrm{PF}$ - pelleted-feed group; ${ }^{2} \mathrm{GF}$ - ground-feed group; ${ }^{3} \mathrm{SEM}$ - pooled standard error of the mean

Mean serum AST, GGT and amylase activities in each group on each sampling date are given in Table 3 . None of these variables differed significantly between groups, or showed a significant $\mathrm{G} \times \mathrm{T}$ interaction, but all three showed a significant or near-significant influence of time (GGT, $\mathrm{P}<0.001$; AST, $\mathrm{P}=0.085$; amylase, $\mathrm{P}=0.053$ ).

Table 3. Mean values of serum AST, GGT and amylase activities during the study. P values for the effects of time (T) and group $(\mathrm{G})$, and the $\mathrm{G} \times \mathrm{T}$ interaction

\begin{tabular}{|c|c|c|c|c|c|c|c|c|c|c|c|}
\hline \multirow{2}{*}{ Variable } & \multicolumn{6}{|c|}{ Days } & \multicolumn{2}{|c|}{ Mean \pm} & \multicolumn{3}{|c|}{$\mathrm{P}$} \\
\hline & 0 & 3 & 7 & 13 & 51 & 77 & pooled & SEM $^{3}$ & $\mathrm{~T}$ & G & $\mathrm{G} \times \mathrm{T}$ \\
\hline \multicolumn{12}{|l|}{$\overline{\mathrm{AST}}, \mathrm{IU} / \mathrm{l}$} \\
\hline $\mathrm{PF}^{1}$ & 28.61 & 19.07 & 23.85 & 23.03 & 21.17 & 37.34 & 25.51 & 1.67 & 0.085 & 0.794 & 0.542 \\
\hline $\mathrm{GF}^{2}$ & 27.68 & 22.08 & 23.73 & 27.68 & 24.42 & 30.59 & 26.15 & & & & \\
\hline \multicolumn{12}{|l|}{ GGT, IU/1 } \\
\hline PF & 5.79 & 6.34 & 5.39 & 4.56 & 5.07 & 4.20 & 5.23 & 0.22 & $<0.001$ & 0.132 & 0.701 \\
\hline GF & 6.42 & 7.14 & 5.83 & 5.04 & 4.91 & 5.15 & 5.75 & & & & \\
\hline \multicolumn{12}{|c|}{ Amylase, IU/1 } \\
\hline PF & 82.64 & 71.96 & 85.80 & 76.31 & 87.30 & 93.97 & 83.01 & 6.86 & 0.053 & 0.230 & 0.163 \\
\hline GF & 76.31 & 85.40 & 89.75 & 98.85 & 129.70 & 95.68 & 95.95 & & & & \\
\hline
\end{tabular}

${ }^{1} \mathrm{PF}$ - pelleted-feed group; ${ }^{2} \mathrm{GF}$ - ground-feed group; ${ }^{3} \mathrm{SEM}$ - standard error of the mean 


\section{DISCUSSION}

None of the animals in this study ever exhibited clinical signs of ruminal disturbances associated with high-processed grains (Lorenz, 2004). We attribute this finding to two nutritional reasons (Castillo et al., 2011): 1. the barley straw used as forage and 2. the high amount of $\mathrm{CP}$ of the ration. Barley straw promotes chewing activity and saliva secretion, preventing acid overload, and ameliorating digestive disturbances. On the other hand, high $\mathrm{CP}$ content may act as a ruminal $\mathrm{pH}$ buffer, especially in the group fed the pelleted ration, which showed more stable acid-base balance over time, although with less base excess and $\mathrm{HCO}_{3}^{-}$ values (Castillo et al., 2006). In this context, blood parameters indicate that, except for creatinine and the unexplained $\mathrm{G} \times \mathrm{T}$ interaction shown by the SUN data, processing technique had no influence on the nutritional value of the ration. Animal performance was reported elsewhere (Suárez, 2009). Briefly, no significant differences were found between groups (Table 4) although it seems that the pelleted feed produced slightly superior feed efficiency compared to coarser particles, as can be seen by the higher ADG and lower feed:gain ratio in PF calves than in GF calves. Then, the higher creatinine concentrations observed in PF group are coherent with performance observations, in spite of the lacking statistical significance, notably the greater initial and final weights of group PF. In fact, serum creatinine is correlated with body muscle mass and this finding supports the general idea that processed grains are more productively efficient than ground grains (Owens et al., 1997; Beauchemin et al., 2001).

Table 4. Productive performance (means and $\mathrm{SEM}^{1}$ ) of finishing-stage bull calves (Suárez, 2009)

\begin{tabular}{|c|c|c|c|c|}
\hline \multirow{2}{*}{ Item } & \multicolumn{2}{|c|}{ Groups } & \multirow{2}{*}{$\mathrm{P}$} & \multirow{2}{*}{$\mathrm{SEM}^{3}$} \\
\hline & $\mathrm{PF}^{1}$ & $\mathrm{GF}^{2}$ & & \\
\hline Initial liveweight, kg & 237 & 232 & ns & 1.61 \\
\hline Final weight, kg & 430 & 420 & ns & 2.06 \\
\hline $\mathrm{ADG}, \mathrm{kg}$ & 1.59 & 1.55 & ns & 0.02 \\
\hline Daily intake, kg/d & 8.0 & 8.1 & ns & 0.08 \\
\hline Feed:gain ratio & 5.0 & 5.2 & ns & 0.09 \\
\hline
\end{tabular}

${ }^{1} \mathrm{PF}$ - pelleted-feed group; ${ }^{2} \mathrm{GF}$ - ground-feed group; ${ }^{3} \mathrm{SEM}$ - pooled standard error of the mean; ns - not significant

Most parameters exhibited significant or tendency towards variation in time, which in the case of parameters showing consistent trends in keeping with reports that ruminal function improves with age (Khan et al., 2007; Kaneko et al., 2008). Then, the question that arises from these results is about the lack of effect of grain processing on metabolism if theoretically, increasing the structural disruption of grain should increase the availability of glucose precursors and change protein solubility in rumen (Beauchemin et al., 2001). 
In our study, serum glucose levels were indeed considerably above the normal range of $45-75 \mathrm{mg} / \mathrm{dl}$ mentioned in the literature for cattle in general (Kaneko et al., 2008), and attributable to the high grain content in both diets (Castillo et al., 2011): the difference in starch availability between pelleted and ground feed seems to have been insufficient to give rise to a significant betweengroup difference in serum glucose concentration. Although starch availability increases with processing grain, in general, considerable differences can exist depending on the technique employed. Thus, under the conditions of our study, pelleting or ground grains seem not to induce changes in glucose precursors (propionate and lactate). This finding is in accordance with the lack of influence of grain processing on serum L-lactate. Ruminal function was not directly characterized in this study by measurement of ruminal parameters, but blood L-lactate levels have been reported to be closely associated with ruminal L-lactate (Montaño et al., 1999). The numerically higher L-lactate concentrations in PF group only suggest somewhat better digestion of starch in the rumen, without other consequences. This finding is in keeping with the similarly ambiguous ruminal L-lactate data obtained by Secrist et al. (1996) in steers fed diets with $82 \%$ of rolled or whole-grain maize. Other authors (Brown et al., 2000) observed no significant influence of grain processing on the serum L-lactate concentration of finishing steers fed diets with $77 \%$ steam-flaked or dry-rolled maize, but Lozano et al. (2005) reported that net absorption of lactate across the gut of steers fed $77 \%$ sorghum diets increased as the density of steam-flaked maize fell. Under our experience from previous reports (Castillo et al., 2009), L-lactate concentration seem to be conditioned for the grain source (rapidly digested grain vs more slowly digested grain) more than the processing technique.

In keeping with their high serum glucose levels, both groups had normal serum NEFA concentrations at any time, without between-group differences, indicating that all the animals were in a positive energy balance, independent of the grain processing method.

In relation to protein metabolism, both groups did not differ in either TSP or albumin concentrations. Nevertheless, the fluctuations observed in SUN values indicate changes in protein digestion depending on group. The time course of the interaction is puzzling although note that in most of the data, PF calves had higher SUN concentration than GF calves. This finding shows that, effectively, grain processing seems to affect the recycling of urea, increasing the supply of high-quality microbial protein for absorption, as was described for growing beef steers by Alio et al. (2000) and Theurer et al. (2002), and in accordance with the productive results found in the study of Suárez (2009).

The increase in AST activity during the study period is attributable to increased liver activity associated with high-grain consumption (Latimer et al., 2003); in 
view of the perfectly normal GGT values (and their time course), it is unlikely to have resulted from hepatobiliary damage (Latimer et al., 2003). The fact that serum amylase activities were higher towards the end of the study than during the first week is indicative of increased digestion of ruminal fermentation products and escape nutrients with age (Xu et al., 2009). The absence of a significant between-group difference in amylase activity is in line with our results in glucose and L-lactate values. In conclusion, grain processing (ground or pelleted) did not modify ruminal and intestinal starch digestion.

\section{CONCLUSIONS}

Under the conditions of this study, most of the parameters studied underwent significant variation in time, but the only statistically significant difference between processing methods (pelleting vs ground) concerned creatinine (higher in calves fed pelleted concentrate, in keeping with its greater average body weight) and urea nitrogen (which for unknown causes fluctuated in opposite directions in the two groups throughout most of the study and attributable to changes in ruminal protein digestion). Neither serum glucose nor L-lactate were affected by treatment of grains. Other nutritional factors, such as forage fibre source and/or $\mathrm{CP}$ content may influence these findings. Finally, taking into account productive and metabolic data the administration of concentrate in a ground form for feedlot is recommended.

\section{ACKNOWLEDGEMENTS}

The authors thank Lucía Casanova for her technical assistance.

\section{REFERENCES}

AFNOR, Association Française de Normalisation, 1997. Aliments des Animaux. Dosage de l'AzoteMéthode par Combustion (DUMAS). Procedure ID: NFV 18-120, Paris

Alio A., Theurer C.B., Lozano O., Huber J.T., Swingle R.S., Delgado-Elorduy A., Cuneo P., DeYoung D.,Webb Jr. K.E., 2000. Splanchnic nitrogen metabolism by growing beef steers fed diets containing sorghum grain flaked at different densities. J. Anim. Sci. 78, 1355-1363

Beauchemin K.A., Yang W.Z., Rode L.M., 2001. Effects of barley grain processing on the site and extent of digestion of beef feedlot finishing diets. J. Anim. Sci. 79, 1925-1936

Brown M.S., Krehbiel C.R., Duff G.C., Galyean M.L., Hallford D.M., Walker D.A., 2000. Effect of degree of corn processing on urinary nitrogen composition, serum metabolite and insulin profiles, and performance by finishing steers. J. Anim. Sci. 78, 2464-2474 
Castillo C., Benedito J.L., Pereira V., Vázquez P., Gutiérrez C., Hernández J., 2009. Acid-base status and serum L-lactate in growing/finishing bull calves fed different high-grain diets, Livest. Sci. $120,66-74$

Castillo C., Hernández J., Méndez J., Lena J., Pereira V., López M., Benedito J.L., 2006. Influence of grain processing on acid-base balance in feedlot steers, Vet. Res. Commun. 30, 823-837

Castillo C., Hernandez J., Pereira V., Vazquez P., Sotillo J., Lopez Alonso M., Miranda M., Benedito J.L., 2011. Serum metabolite concentrations and enzyme activities in finishing bull calves fed different types of high-grain diets. Arch. Tierzucht 54, 137-146

Commission Directive 1981/680/EC, 1981. Official Journal of the European Communities, 30 July 1981; (L246): 0032-0035. http://eur-lex.europa.eu/es/index.htm

Commission Directive 1998/64/EC., 1998. Official Journal of the European Communities, 3 September 1998; (L257): 0014-0028. http://eur-lex.europa.eu/es/index.htm

Commission Directive 1999/79/EC, 1999. Official Journal of the European Communities, 27 July 1999; (L209): 0023-0027. http://eur-lex.europa.eu/es/index.htm

Dehghan-Banadaky M., Corbett R., Oba M., 2007. Effects of barley grain processing on productivity of cattle. Anim. Feed Sci. Tech. 137, 1-24

Kaneko J.J., Harvey J.W., Bruss M.L. (Editors), 2008. Clinical Biochemistry of Domestic Animals. $6^{\text {th }}$ revised Edition. Academic Press, Orlando, pp. 45-80

Khan M.A., Lee H.J., Lee W.S., Kim H.S., Ki K.S., Park S.J., Ha J.K., Choi Y.J., 2007. Starch source evaluation in calf starter: I. Feed consumption, body weight gain, structural growth and blood metabolites in Holstein calves. J. Dairy Sci. 90, 5259-5268

Latimer K.S., Mahaffey E.A., Prasse K.W. (Editors), 2003. Duncan \& Prasse's Veterinary Laboratory Medicine: Clinical Pathology. $4^{\text {th }}$ revised Edition. Iowa State University Press. Iowa, pp. $193-$ 214

Lorenz I., 2004. Investigations on the influence of serum D-lactate levels on clinical signs in calves with metabolic acidosis. Vet. J. 168, 323-327

Lozano O., Theurer C.B., Alio A., Huber J.T., Delgado-Elorduy A., Cuneo P., DeYoung D., Sadik M., Swingle R.S., 2005. Net absorption and hepatic metabolism of glucose L-lactate and volatile fatty acids by steers fed diets containing sorghum grain processed as dry-rolled or steam-flaked at different densities. J. Anim. Sci. 78, 1364-1371

Lumsden J.H., 2000. Laboratory test methods validation. Rev. Méd. Vét. 151 , 623-630

Montaño M.F., Chai W., Zinn-Ware T.E., Zinn R.A., 1999. Influence of malic acid supplementation on ruminal $\mathrm{pH}$, lactic acid utilization, and digestive function in steers fed high-concentrate finishing diets. J. Anim. Sci. 77, 780-784

Owens F.N., Secrist D.S., Hill W.F., Gill D.R., 1997. The effect of grain source and grain processing on performance of feedlot cattle: a review. J. Anim. Sci. 75, 868-879

Real Decreto 1201/2005. Boletín Oficial del Estado (BOE), 21 Octubre 2005, número 252: 3436734388. http://boe.es/boe/dias/2005/10/21/pdfs/A34367-34391.pdf

Secrist D.S., Owens F.N., Hill W.J., Welty S.D., 1996. Rolled versus whole corn: effects on ruminal fermentation of feedlot steers. Oklahoma Agric. Exp. Sta. Misc. Publ. P-951, OK, pp. 181-188

Suárez A., 2009. Technologic measures preventing ruminal acidosis in feedlot: grain processing. Master Degree, Veterinary Faculty, Lugo, University of Santiago de Compostela, Lugo, pp. 77-78

Theurer C.B., Huntington G.B., Huber J.T., Swingle R.S., Moore J.A., 2002. Net absorption and utilization of nitrogenous compounds across ruminal, intestinal, and hepatic tissues of growing beef steers fed dry-rolled or steam-flaked sorghum grain. J. Anim. Sci. 80, 525-532

Van Soest P.J., Robertson J.B., Lewis B.A., 1991. Methods for dietary fiber, neutral detergent fiber, and non-starch polysaccharides in relation to animal nutrition. J. Dairy Sci. 74, 3583-3597

Xu M., Du S., Wang J., Yu Z.P., Harmon D.L., Yao J.H., 2009. Influence of rumen escape starch on pancreatic exocrine secretion of goats. J. Anim. Physiol. Anim. Nutr. 93, 122-129 